\title{
Isolation and identification of mRNA for the high-molecular-weight storage proteins of wheat endosperm
}

\author{
J. Forde and B.J. Miflin \\ Biochemistry Department, Rothamsted Experimental Station, Harpenden, Herts. AL5 2JQ, UK
}

\begin{abstract}
The prolamin storage proteins of the wheat endosperm contain a sub-class of high-molecular-weight (HMW) polypeptides which have been implicated in determining breadmaking quality. Membrane-bound polysomes isolated from developing wheat endosperms contain mRNA for these HMW components. Although unfractionated polyadenylated RNA derived from the polysomes did not direct the synthesis of these components in an in-vitro wheat-germ system, it did when incubated with a rabbit reticulocyte lysate system. Identification of the translation products as HMW prolamins was based on their large incorporation of $\left[{ }^{3} \mathrm{H}\right]$ leucine and $\left[{ }^{3} \mathrm{H}\right]$ glycine relative to $\left[{ }^{3} \mathrm{H}\right]$ lysine, their mobility on polyacrylamide-gel electrophoresis and the observation that the changes of mobility in response to change in wheat genotype were the same as those observed for the authentic protein. The mRNA was fractionated by electrophoresis and density-gradient centrifugation. The mRNA for the HMW prolamins was found to have a relative molecular mass of about $1.6 \cdot 10^{6}$.
\end{abstract}

Key word: Endosperm (protein) - mRNA - Prolamin - Protein synthesis (in vitro) - Storage protein - Triticum (storage protein).

\section{Introduction}

Mature wheat endosperm contains $10 \%$ protein, over half of which may be termed storage protein and is deposited in protein bodies. The storage protein fraction consists of a polymorphic series

Abbreviations: $\mathrm{HMW}=$ high molecular weight; $\mathrm{PAGE}=\mathrm{po-}$ lyacrylamide-gel electrophoresis; poly $(\mathrm{A})^{+} \mathrm{RNA}=$ polyadenylated RNA; SDS = sodium dodecyl sulphate of proteins which may be classified into a number of sub-groubs. The exact nature of the classification is controversial and confusing (see Kasarda et al. 1976; Miflin and Shewry 1979; Miflin et al. 1980, 1983; Payne and Rhodes 1982 for discussions). However, recent research has shown that protein bodies contain a group of high-molecularweight (HMW) components of apparent relative molecular mass $\left(\mathrm{M}_{\mathrm{r}}\right)$ 80-130 kdalton as determined by sodium dodecyl sulphate - polyacrylamide-gel electrophoresis (SDS-PAGE), or 63-70 kdalton as determined by sedimentation-equilibrium ultracentrifugation (Miflin and Shewry 1979; Khan and Bushuk 1979; Miflin et al. 1981; Field et al. 1982/1983). These HMW components are rich in glutamine and proline, as is characteristic of prolamins, and also contain relatively large amounts of glycine. Although they can be extracted readily by aqueous propan-1-ol (Miflin et al. 1980; Byers et al. 1983) they are only sparingly soluble in $70 \%$ ethanol at $4^{\circ} \mathrm{C}$ and thus have often been termed glutenins.

Payne and coworkers (Payne et al. 1980, $1981 \mathrm{a}$, $b, 1983)$ have described the genetics of several of these components, which they have classified as numbered subunits, and shown that they are coded for by loci near to the centromere on the long arms of the homologous chromosomes of group 1Furthermore, these workers have correlated the presence of certain of these subunits with baking quality (Payne et al. 1979, 1981 a). Other evidence, particularly the presence of the HMW subunits in large aggregates of gluten, also indicates that they have a role in determining breadmaking quality (see Miflin et al. 1983 for review). Recent results (Field et al. 1982) on their amino-acid sequence and protein structure, supports the suggestion (Ewart 1972) that they function in determining the elastic properties of gluten. In order to obtain fur- 
ther information on this group of proteins, we have commenced a study of their molecular biology. However, information on the synthesis of these proteins is lacking. Greene (1981), Donovan et al. (1982) and Okita and Greene (1982) have extracted mRNA from developing wheat endosperms and have identified classical gliadins as components of the cell-free translation products. However, both groups were unable to find any evidence for the cell-free synthesis of the HMW subunits. Such lack of synthesis could be due to trivial procedural causes or because the subunits were synthesized in another form and only processed to their final form at some stage after translation. This paper reports that the mRNAs for HMW subunits are present in developing wheat endosperms and can be translated to give products recognizable as HMW subunits.

\section{Material and methods}

Plant material. Ears of field-grown wheat (Triticum aestivum L. cultivars Highbury, Sentry, Flanders and Brigand) were harvested at mid-maturation (about two to three weeks after anthesis) and the endosperms collected in liquid nitrogen prior to storage at $-80^{\circ} \mathrm{C}$.

Preparation of authentic wheat prolamins. Wheat prolamins were extracted from the milled grain of the four wheat cultivars using $50 \%$ aqueous ( $\mathrm{v} / \mathrm{v})$ propan-1-ol, $2 \%$ 2-mercaptoethanol and $1 \%(\mathrm{v} / \mathrm{v})$ acetic acid at $20^{\circ} \mathrm{C}$ (Miflin et al. 1980). The authentic prolamins were ${ }^{14} \mathrm{C}$-methylated (Dottavio-Martin and Ravel 1978).

Polysome isolation. All solutions and glassware were sterilised. Free and membrane-bound polysomes were isolated using a method adapted from previously published procedures (Larkins and Dalby 1975; Fox et al. 1977; Matthews and Miflin 1980). Frozen endosperms $(100 \mathrm{~g})$ were ground to a fine powder using a coffee mill and the powder homogenised in $300 \mathrm{ml}$ of buffer containing $0.2 \mathrm{M}$ 2-amino-2-(hydroxymethyl)-1,3-propanadiol (Tris)- $\mathrm{HCl} \mathrm{pH} 9,120 \mathrm{mM} \mathrm{KCl}, 50 \mathrm{mM} \mathrm{Mg}$ acetate, $0.2 \mathrm{M}$ sucrose, $5 \mathrm{mM}$ dithiotreitol (DTT), $2 \mathrm{mM} 2^{\prime}$ and $3^{\prime}$ adenosine monophosphate (AMP). The slurry was spun at $200 \mathrm{~g}$ for $10 \mathrm{~min}$, the supernatant filtered through two thicknesses of muslin and spun at $30,000 \mathrm{~g}$ for $25 \mathrm{~min}$. This supernatant is presumed to contain free polysomes. The pellets were resuspended in the same buffer containing $1 \%(\mathrm{w} / \mathrm{v})$ Triton $\mathrm{X}-100$ to solubilise the membrane-bound polysomes and the stripped membranes removed by centrifugation at $30,000 \mathrm{~g}$ for $25 \mathrm{~min}$. The supernatants were layered over $4 \mathrm{ml}$ of $54 \%(\mathrm{w} / \mathrm{w})$ sucrose and the polysomes were pelleted at $250,000 g_{\text {av }}$ for $4 \mathrm{~h}$ at $4^{\circ} \mathrm{C}$. For translation the polysomes were suspended in $10 \mathrm{mM}$ Hepes- $\mathrm{KOH} \mathrm{pH} 7.6,100 \mathrm{mM} \mathrm{KCl}, 4 \mathrm{mM} \mathrm{Mg}$ acetate and $1 \mathrm{mM}$ DTT.

Isolation of RNA. Membrane-bound polysomes were disrupted in SDS buffer $(0.2 \mathrm{M}$ Tris- $\mathrm{HCl} \mathrm{pH} 9,0.1 \mathrm{M} \mathrm{NaCl}, 10 \mathrm{mM}$ ethylenediaminetetraacetic acid (EDTA) and $0.5 \%$ SDS) and deproteinised with phenol-chloroform (Weinand and Feix 1978). The RNA was precipitated at $-20^{\circ} \mathrm{C}$ by the addition of ammonium acetate to $0.2 \mathrm{M}$ and 2.5 volumes of absolute ethanol, washed well with $75 \%$ ethanol, dried under vacuum, and finally taken up in sterile distilled water. The term polysomal RNA refers to this RNA derived from membrane-bound polysomes. Polysomal RNA was chromatographed by one passage through oligo (dT)-cellulose and the unbound RNA eluted with $0.4 \mathrm{M}$ $\mathrm{NaCl}$, the "wash" RNA with $0.1 \mathrm{M} \mathrm{NaCl}$ and the polyadenylated RNA (poly(A) ${ }^{+}$RNA) with a no-salt buffer (Bantle et al. 1976). The RNAs were ethanol-precipitated.

\section{Separation of RNA}

Methlmercury-agarose-gel electrophoresis. Polyadenylated RNA $(60 \mu \mathrm{g})$ was applied in $6 \mathrm{mM}$ methylmercury hydroxide to a $1 \%$ agarose slab gel also containing $6 \mathrm{mM}$ methylmercury hydroxide as the denaturant (Bailey and Davidson 1976). Denatured wheat ribosomal RNA, Escherichia coli ribosomal RNA and calf thymus tRNA (BCL. The Boehringer Corporation (London) Ltd., Lewes, U.K.) were used as markers. After electrophoresis in boric acid-sodium borate $\mathrm{pH} \mathrm{8.2,} \mathrm{some} \mathrm{tracks}$ were placed in $0.5 \mathrm{M}$ ammonium acetate, stained with ethidium bromide and photographed over a UV light box. The rest of the gel was sliced into $0.5 \mathrm{~cm}$ strips, placed in dialysis sacks and the RNA electro-eluted for $2-3 \mathrm{~h}$ in the same buffer. The current was reversed for $1 \mathrm{~min}$, the RNA collected, precipitated, washed three times in $75 \%$ ethanol, and finally taken up in sterile distilled water.

Sucrose-density-gradient centrifugation. Polyadenylated RNA was fractionated by centrifugation on sucrose gradients made by layering $1.2 \mathrm{ml}$ of $50,40,20$ and $10 \%(\mathrm{w} / \mathrm{v})$ sucrose in $95 \%$ dimethyl sulfoxide (DMSO), $4 \%$ formamide, $10 \mathrm{mM}$ Tris, $10 \mathrm{mM} \mathrm{LiCl}$ and $1 \mathrm{mM}$ EDTA, and allowing diffusion at room temperature overnight (Beachy et al. 1980). The RNA was taken up in buffer containing $10 \mathrm{mM}$ Tris, $10 \mathrm{mM} \mathrm{LiCl}, 1 \mathrm{mM}$ EDTA and $10 \%$ DMSO, heated to $60^{\circ} \mathrm{C}$ for $5 \mathrm{~min}$, chilled on ice, and $30 \mu \mathrm{g}$ poly $(\mathrm{A})^{+}$RNA loaded per gradient. The gradients were centrifuged for $48 \mathrm{~h}$ at $150,000 \mathrm{~g}_{\mathrm{av}}$ in a Beckman (High Wycombe, U.K.) SW 40.1 rotor at $26^{\circ} \mathrm{C}$. They were fractionated into $0.2-\mathrm{ml}$ fractions and their absorbance at $280 \mathrm{~nm}$ monitored using an Isco (MSE Scientific Supplies, Crawley, U.K.) density-gradient fractionator (Model 640). Carrier tRNA ( $5 \mu \mathrm{g}$, Boehringer, calf thymus) was added to each, the RNA ethanol precipitated, washed well with $75 \%$ ethanol, and taken up in sterile distilled water. The fractions were translated in the rabbit reticulocyte lysate as described below and those encoding the HMW polypeptides were pooled. This RNA was boiled for $1 \mathrm{~min}$ in $10 \mathrm{mM}$ Tris, $10 \mathrm{mM} \mathrm{LiCl}, 1 \mathrm{mM}$ EDTA, chilled rapidly, and loaded onto a 5 to $20 \%$ (w/v) sucrose gradient and centrifuged for $24 \mathrm{~h}$ at $150,000 \mathrm{~g}_{\text {av }}$ at $20^{\circ} \mathrm{C}$. The RNA was fractionated and precipitated as before, prior to translation.

Protein synthesis in vitro. The reticulocyte lysate was prepared and used as described by Pelham and Jackson (1976). The lysate contained $1 \mathrm{mM} \mathrm{Ca}^{2+}, 2 \mathrm{mM}$ ethylene glycol bis ( $\beta$-aminoethyl

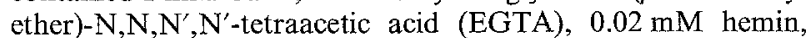
$0.5 \mathrm{mg} \mathrm{ml}^{-1}$ tRNA, $2 \mathrm{mM}$ dithiothreitol, $10 \mathrm{mM}$ creatine phosphate, $50 \mu \mathrm{g} \mathrm{ml}^{-1}$ creatine kinase and $50 \mu \mathrm{M}$ of various amino acids excluding that used as label. The final concentrations of $\mathrm{K}^{+}$and $\mathrm{Mg}^{2+}$ were $100 \mathrm{mM}$ and $1.45 \mathrm{mM}$ respectively and $\mathrm{L}-\left[{ }^{35} \mathrm{~S}\right]$ methionine was at a concentration of $9.3-18.5 \mathrm{kBq} \mu \mathrm{l}^{-1}$. The poly(A) ${ }^{+}$RNA was added at concentrations up to $160 \mu \mathrm{g}$ $\mathrm{mi}^{-1}$ and in a maximum volume of $20 \%$ of the lysate volume. The optimum was found to be approx. $20 \mu \mathrm{g} \mathrm{ml}^{-1}$. Incubations were carried out in $12-\mu 1$ or $24-\mu \mathrm{l}$ volumes at $30^{\circ} \mathrm{C}$ for $90 \mathrm{~min}$.

The wheat-germ $(30,000 \mathrm{~g})$ supernatant was prepared and used as published (Roberts and Paterson 1973; Matthews and 
Miflin 1980). The poly(A) ${ }^{+}$RNA and "wash" RNA were added at varying concentrations up to $100 \mu \mathrm{g} \mathrm{ml}^{-1}$; unbound RNA and polysomal RNA were added at a concentration of $600 \mu \mathrm{g} \mathrm{ml}^{-1}$. All RNAs were heated to $65^{\circ} \mathrm{C}$ for $5 \mathrm{~min}$ and chilled on ice before addition to the translation mixture. Translations were done in a $40-\mu 1$ volume using various labelled amino acids, the final concentrations of which were: $\left[{ }^{3} \mathrm{H}\right]$ glycine and $\left[{ }^{3} \mathrm{H}\right]$ serine, $740 \mathrm{kBq} ; \quad\left[{ }^{3} \mathrm{H}\right]$ proline, $\left[{ }^{3} \mathrm{H}\right]$ leucine and $\left[{ }^{3} \mathrm{H}\right]$ lysine, $370 \mathrm{kBq} ;\left[{ }^{35} \mathrm{~S}\right]$ methionine, $148-740 \mathrm{kBq}$.

Analysis of translation products. Polypeptide products were analysed by SDS-PAGE on gels ranging from 8 to $16 \%(\mathrm{w} / \mathrm{v})$ acrylamide (Laemmli 1970). Sample buffer was added to the translation mix so that the final concentrations of SDS and 2 -mercaptoethanol were $5 \%$, and heated to $70^{\circ} \mathrm{C}$ for $20 \mathrm{~min}$ before loading onto the gel. Alkylated samples were shaken in a $0.5 \%$ solution of 4 -vinylpyridine for $2 \mathrm{~h}$ before the addition of sample buffer. Alternatively the translation mixtures were made to $50 \%(\mathrm{v} / \mathrm{v})$ propan-1-ol, 2\% 2-mercaptoethanol and $1 \%$ acetic acid and the prolamins extracted at $60^{\circ} \mathrm{C}$ for $10 \mathrm{~min}$. The pellets obtained after centrifugation were re-extracted twice at $60^{\circ} \mathrm{C}$ with the same solution. The supernatants were pooled and neutralised with Tris base before alkylation. The prolamins were precipitated overnight in $2 \% \mathrm{LiCl}$ and $0.4 \% 2$-mercaptoethanol, the pellets washed twice with water and taken up in sample buffer.

After electrophoresis the gel was fixed in $10 \% \mathrm{w} / \mathrm{v}$ trichloroacetic acid and $40 \% \mathrm{v} / \mathrm{v}$ methanol for $2 \mathrm{~h}$ and stained for $1 \mathrm{~h}$ with $0.1 \%$ Coomassie Brilliant Blue R250 in 5\% acetic acid and $45 \%$ methanol. To prevent possible loss of the HMWpolypeptide translation products from the gel, prolonged staining and destaining in methanol-acetic acid solutions, ideal solvents for these proteins, was avoided. Gels were destained with $5 \%$ trichloroacetic acid, treated with sodium salicylate (Chamberlain 1979), dried and fluorographed.

The following proteins were used as molecular-weight markers: phosphorylase B (100 and 92.5 kdalton), bovine serum albumin ( 66 kdalton), ovalbumin ( 45 kdalton), pepsin (34.7 kdalton), trypsinogen (24 kdalton), lactoglobulin (18.4 kdalton) and lysozyme (14.3 kdalton).

\section{Results and discussion}

Characterisation of polysome translation products. The translation products of membrane-bound and free polysomes are shown in Fig. 1 (tracks b, c). The products represent those soluble in an alcohol solvent (containing 1\% acetic acid and 2\% 2-mercaptoethanol) and are therefore enriched for prolamin polypeptides (Osborne 1924; Miflin et al. 1980). Comparison of tracks $b$ and $c$ shows that the HMW polypeptides of molecular weight between about 80 and 130 kdalton are synthesised predominantly on the membrane-bound polysomes. This is in agreement with the site of synthesis for the prolamin storage proteins of wheat (Greene 1981; Donovan et al. 1982), barley (Brandt and Ingversen 1976; Fox et al. 1977) and maize (Larkins and Dalby 1975; Burr and Burr 1976). Some products appear to be common to both classes of polysome and it is likely that some

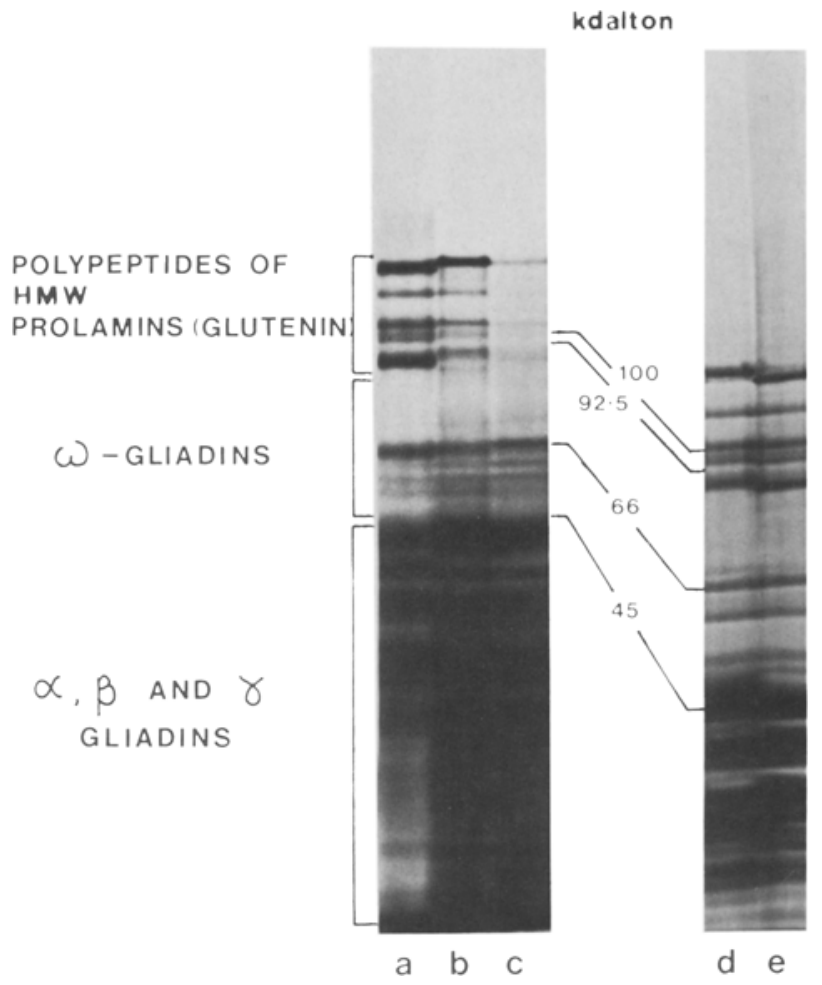

Fig. 1. Polysome products synthesised in vitro. Membranebound and free polysomes from wheat (cv. Highbury) were isolated as described in the text and used in a wheat-germ translation assay. The synthesised products were extracted with $50 \%$ propan-1-ol, 1\% acetic acid and 2\% 2-mercaptoethanol and those soluble were resolved by SDS-PAGE on $10 \%$ polyacrylamide gels, and analysed by fluorography. $a$, Alkylated authentic ${ }^{14} \mathrm{C}$-radiolabelled prolamins; $b$, unalkylated in-vitro translation products of membrane-bound polysomes; $c$, unalkylated in-vitro translation products of free polysomes. Lanes $d$ and $e$ show authentic prolamin proteins run on $7.5 \%$ gels and stained with Coomassie Blue; $d$, unalkylated; $e$, alkylated

contamination of the free polysomes with membrane-bound has occurred.

The difference between the mobilities of the HMW polypeptides synthesised by the polysomes and the radiolabelled authentic proteins (Fig. 1, tracks $\mathrm{a}, \mathrm{b}$ ) is a consequence of sample preparation. The authentic prolamins were alkylated using 4-vinylpyridine whereas the polysome translation products were not. Tracks d and e of Fig. 1 show the increase in mobility which results when the HMW polypeptides are pyridylethylated.

The results of experiments comparing the incorporation of different amino acids into the translation products of membrane-bound polysomes from wheat endosperm and mRNA from rabbit reticulocytes, are shown in Fig. 2. Estimates of the proline:leucine:lysine were made and values of $3.5: 11: 1$ were obtained for the radioactive trichloroacetic-acid-precipitable polypeptides synthe- 


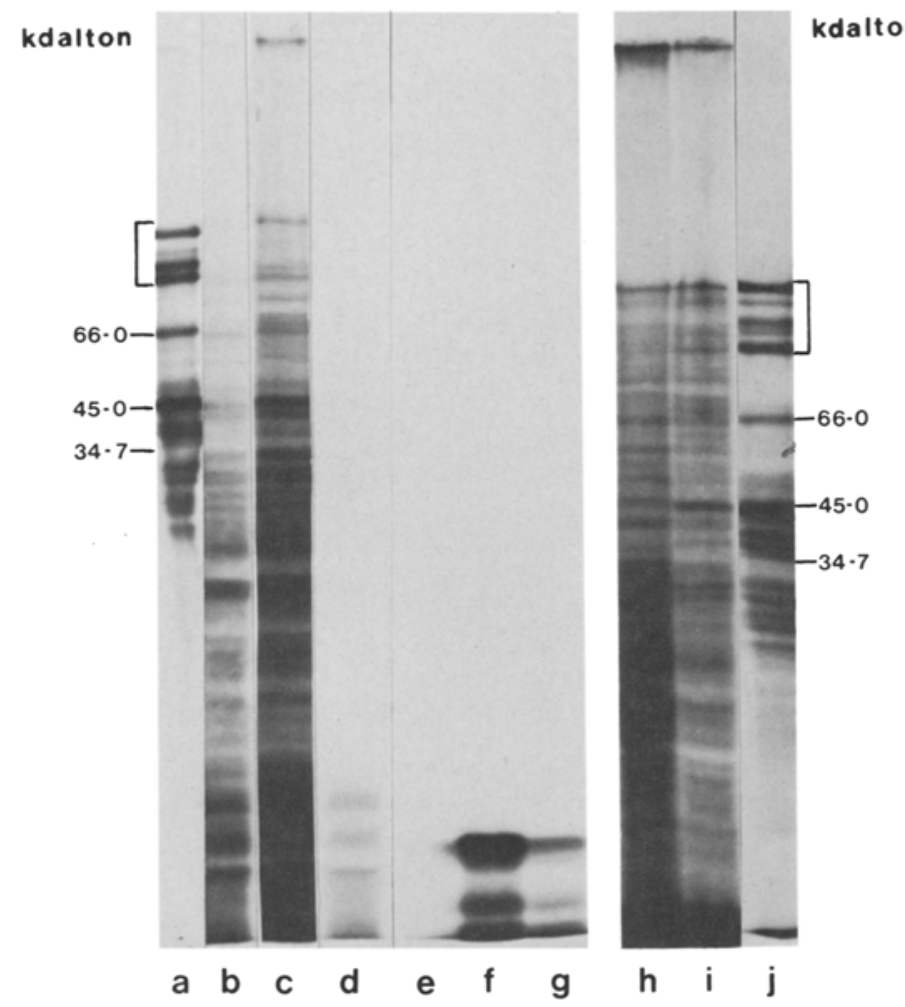

Fig. 2. Characterisation of products obtained on translation of membrane-bound polysomes from wheat (cv. Highbury) and rabbit reticulocyte mRNA using different labelled amino acids in the wheat-germ system. Products were alkylated, run on $12 \%$ (lanes $a-g$ ) and 10\% (lanes $h-j$ ) polyacrylamide gels and fluorographed. $a, j$. Alkylated authentic radiolabelled prolamins; $b$, $c, d, h, i$, Translation products of membrane-bound polysomes using tritiated proline, leucine, lysine, serine or glycine, respectively, in the assay; $e, f, g$, translation products of reticulocyte mRNA using tritiated proline, leucine or lysine in the wheatgerm assay. The bracket indicates the position of the HMW prolamin polypeptides

sised by wheat polysomes and $0.31: 3.9: 1$ for those of globin mRNA. The autoradiograph shows the total translation products of both templates. The majority of wheat polypeptides above 35 kdalton are storage proteins, the HMW prolamin polypeptides being characterised by their low mobility on SDS-polyacrylamide gels. The major albumin and globulin proteins of wheat are reported to have molecular weights much lower than these HMW polypeptides (Pence and Elder 1953; Kasarda et al. 1976). Unlike globin protein, the wheat proteins are more heavily labelled by $\left[{ }^{3} \mathrm{H}\right]$ proline than by $\left[{ }^{3} \mathrm{H}\right]$ lysine (tracks $b, \mathrm{~d}$ and $\mathrm{e}, \mathrm{g}$ ). This result agrees with the known amino-acid compositions of these proteins. Wheat storage proteins, like those of other cereals, have a high proline $(18 \mathrm{~mol} \%)$ and a low lysine content $(0.6 \mathrm{~mol} \%)$ with leucine at an intermediate level ( $5 \mathrm{~mol} \%$ ) (Bietz et al. 1977; Shewry et al. 1980; Miflin et al. 1982; Field et al.
1982). Therefore a high proline:lysine ratio is a characteristic of these proteins. This contrasts with the values of $3.9 \mathrm{~mol} \%$ and $8.4 \mathrm{~mol} \%$ for the proline and lysine residues of globin protein, with leucine at $12.2 \mathrm{~mol} \%$ (Dayhoff 1972). Although this result is clear, the level of $\left[{ }^{3} \mathrm{H}\right]$ proline incorporation by the wheat polysomes was much lower than expected, with poor labelling of HMW translation products. This anomaly has also been reported in a similar experiment using mRNA from barley endosperm (Forde et al. 1981).

To identify more specifically the HMW polypeptides amongst the translation products, the amino acids glycine and serine were used. A characteristic of the HMW polypeptides is their high glycine content $(15 \mathrm{~mol} \%$ ) compared to the lowermolecular-weight $\alpha, \beta$ and $\gamma$ and $\omega$ gliadins $(2 \mathrm{~mol} \%)$. The serine content of all types of prolamin is about $5 \mathrm{~mol} \%$ (Bietz et al. 1977; Khan and Bushuk 1979; Shewry et al. 1980; Field et al. 1982). In Fig. 2, tracks $h$ and i show the translation products of wheat polysomes labelled with $\left[{ }^{3} \mathrm{H}\right]$ serine and $\left[{ }^{3} \mathrm{H}\right]$ glycine respectively. Approximately the same number of cpm were loaded onto each track. The HMW polypeptides are labelled more heavily using $\left[{ }^{3} \mathrm{H}\right]$ glycine, while much less radioactivity appears in the lower-molecularweight region of the gel.

Translation of $R N A$. When poly(A) ${ }^{+}$RNA was prepared from the membrane-bound polysomes of the cultivar Highbury and translated in the wheatgerm protein-synthesising system, the HMW polypeptides were never detected by SDS-PAGE and fluorography, although occasionally the lowestmolecular-weight HMW polypeptide was present. Tracks $\mathrm{a}, \mathrm{b}$ and $\mathrm{c}$ of Fig. $3 \mathrm{~A}$ show the alcoholsoluble translation products of polysomes, poly(A) ${ }^{+}$RNA and "wash" RNA, respectively. Track $d$ shows the polypeptides that remain in the residue after extraction of the poly(A) ${ }^{+}$RNA-directed translation products with the alcohol solvent. No HMW polypeptides are present in tracks $b, c$ or $d$, giving no evidence for the presence of their mRNAs in the poly $(\mathrm{A})^{+}$RNA preparation.

To check the possibility that the RNA was being degraded after release from the polysomes, the ribonuclease inhibitor, heparin, was added at a concentration of $50 \mu \mathrm{g}$ (10 nits) $\mathrm{ml}^{-1}$ to the $54 \%$ sucrose pad through which the polysomes were pelleted. Total poly(A) ${ }^{+}$RNA was also prepared by direct phenol-chloroform extraction of the ground tissue to remove any ribonuclease present at an early stage. Also, in case the endosperm from the 

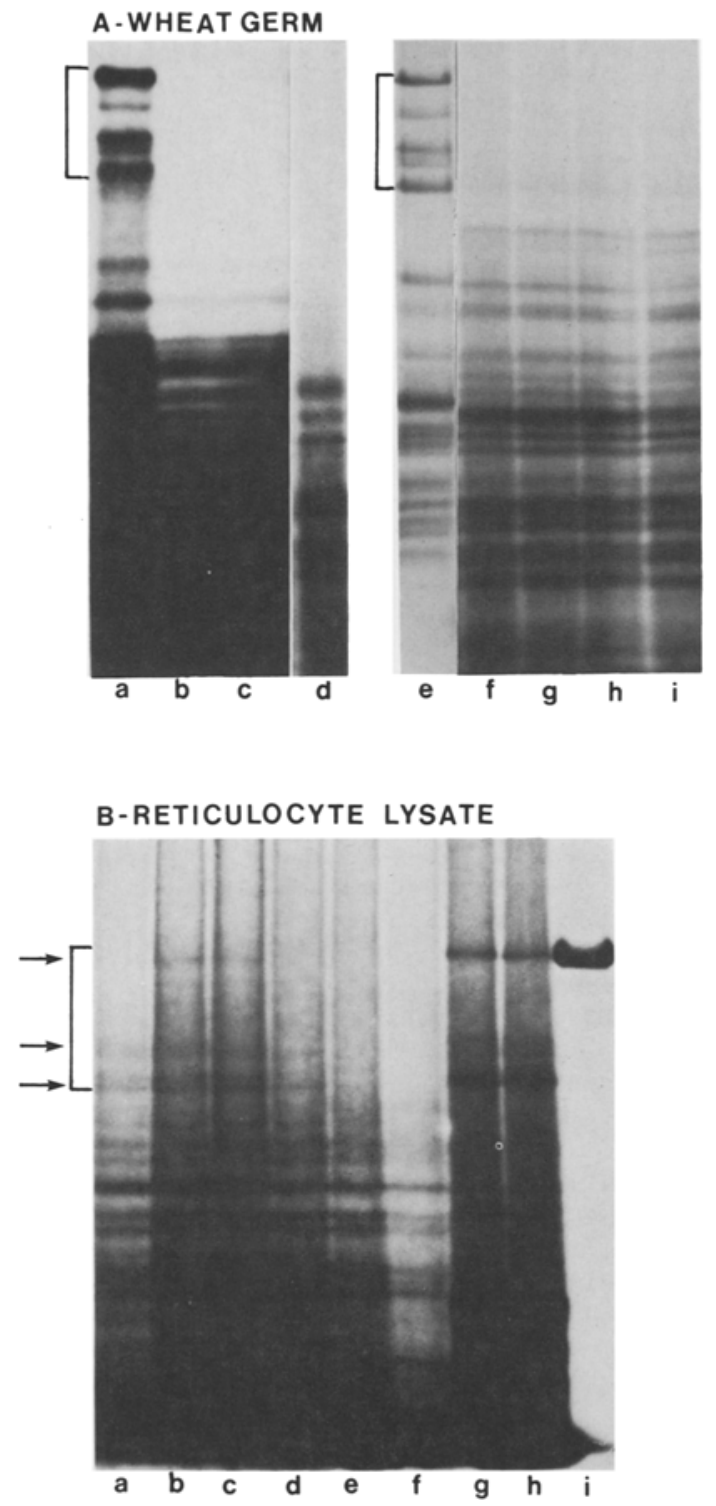

Fig. 3A, B. Products synthesised by endosperm poly(A) ${ }^{+}$RNA (cv. Highbury) in the wheat-germ system (A) and the reticulocyte lysate (B) and the effect of poly $(\mathrm{A})^{+}$RNA concentration on its translation in the two systems. The unalkylated products were separated by SDS-PAGE and the gels dried and fluorographed. A $a, b, c$, Alcohol-soluble translation products of membrane-bound polysomes, "wash" RNA, and poly $(\mathrm{A})^{+}$ RNA, respectively; $d$, proteins remaining in the residue after alcohol extraction of the translation products of poly $(\mathrm{A})^{+}$ RNA; $e$, authentic radiolabelled prolamins; $f, g, h, i, 200 \mu \mathrm{g}$, $100 \mu \mathrm{g}, 50 \mu \mathrm{g}, 25 \mu \mathrm{g}$, respectively of poly(A) ${ }^{+} \mathrm{RNA} \mathrm{ml}^{-1}$ wheat-germ assay. No bands were seen when RNA was omitted from the assay. B $a, b, c, d, e, f, 6.25 \mu \mathrm{g}, 12.5 \mu \mathrm{g}, 25 \mu \mathrm{g}, 50 \mu \mathrm{g}$, $100 \mu \mathrm{g}, 200 \mu \mathrm{g}$ respectively of poly(A) ${ }^{+} \mathrm{RNA} \mathrm{ml}^{-1}$ of reticulocyte lysate. Two faint bands of about 45 and $25 \mathrm{kdalton}$ were present without added RNA. $g$, $h$, Translation products of membrane-bound polysomes in the wheat-germ system; $i$, radiolabelled pyridiylethylated subunit 2 from Highbury. The arrows refer to polypeptides discussed in the text. The brackets indicate the position of the HMW prolamin polypeptides run on differing percentage acrylamide gels cultivar Highbury might have a high endogenous content of nuclease other cultivars were tried as sources of polysomal poly $(\mathrm{A})^{+}$RNA: Greene (1981) has reported high ribonuclease levels in the endosperm of two wheat cultivars used for the isolation of gliadin mRNA. None of these methods improved the ability of the RNA to direct the synthesis of the HMW polypeptides. Attempts to improve the wheat-germ translation system by optimising the $\mathrm{Mg}^{2+}$ and $\mathrm{K}^{+}$concentrations, adding from $0.25-2.0 \mu \mathrm{g}$ of wheat-germ tRNA and including pancreatic ribonuclease inhibitor in the assay, also all failed to result in the synthesis of HMW polypeptides. Figure $3 \mathrm{~A}$ (tracks e-i) shows that decreasing the RNA concentration from 200 to $25 \mu \mathrm{g} \mathrm{ml}{ }^{-1}$ of translation mix had little effect upon the pattern of products obtained. Heating the poly $(\mathrm{A})^{+} \mathrm{RNA}$ to $100^{\circ} \mathrm{C}$ for $45 \mathrm{~s}$ prior to translation, in order to disrupt possible RNARNA appregates did not lead to the presence of HMW translation products even though a marked stimulation (approx. $40 \%$ increase) in the number of counts was obtained.

Two approaches did result in the presence of HMW polypeptides amongst the translation products of wheat RNA. Firstly, when the rabbit reticulocyte lysate was used to translate the poly(A) ${ }^{+}$ RNA, these proteins were synthesised, although their presence was markedly dependent on the concentration of RNA in the assay (Fig. 3B). The maximum incorporation of radioactivity was obtained with an RNA concentration of approx. $20 \mu \mathrm{g}$ poly(A) ${ }^{+}$RNA $\mathrm{ml}^{-1}$. Under these conditions the largest HMW polypeptide of Highbury (termed subunit 2 by Payne et al. 1981 b) is seen (Fig. 3B, tracks b and c, compared with track i). The patterns of HMW polypeptides synthesised by Highbury poly(A) ${ }^{+}$RNA in the reticulocyte lysate and by Highbury polysomes in the wheat-germ system are comparable (see arrowed regions in Fig. $3 \mathrm{~B}$, tracks b, c, g, h). As for the HMW polypeptides synthesized by polysomes in the wheatgerm system, these poly $(\mathrm{A})^{+}$-directed HMW translation products can be extracted from the reticulocyte lysate using $50 \%$ propan- $1-$ ol, with $1 \%$ acetic acid and 2\% 2-mercaptoethanol, indicating their prolamin nature (result not shown).

Secondly, when polysomal RNA was translated in the wheat-germ system HMW polypeptides were formed. Fig. 4B, D (tracks b, c, d, h) show such polypeptides present among the translation products of polysomal RNA from the cultivars Brigand, Sentry, Flanders and Highbury respectively. This result indicates that the mRNAs encoding these proteins may be partially lost dur- 


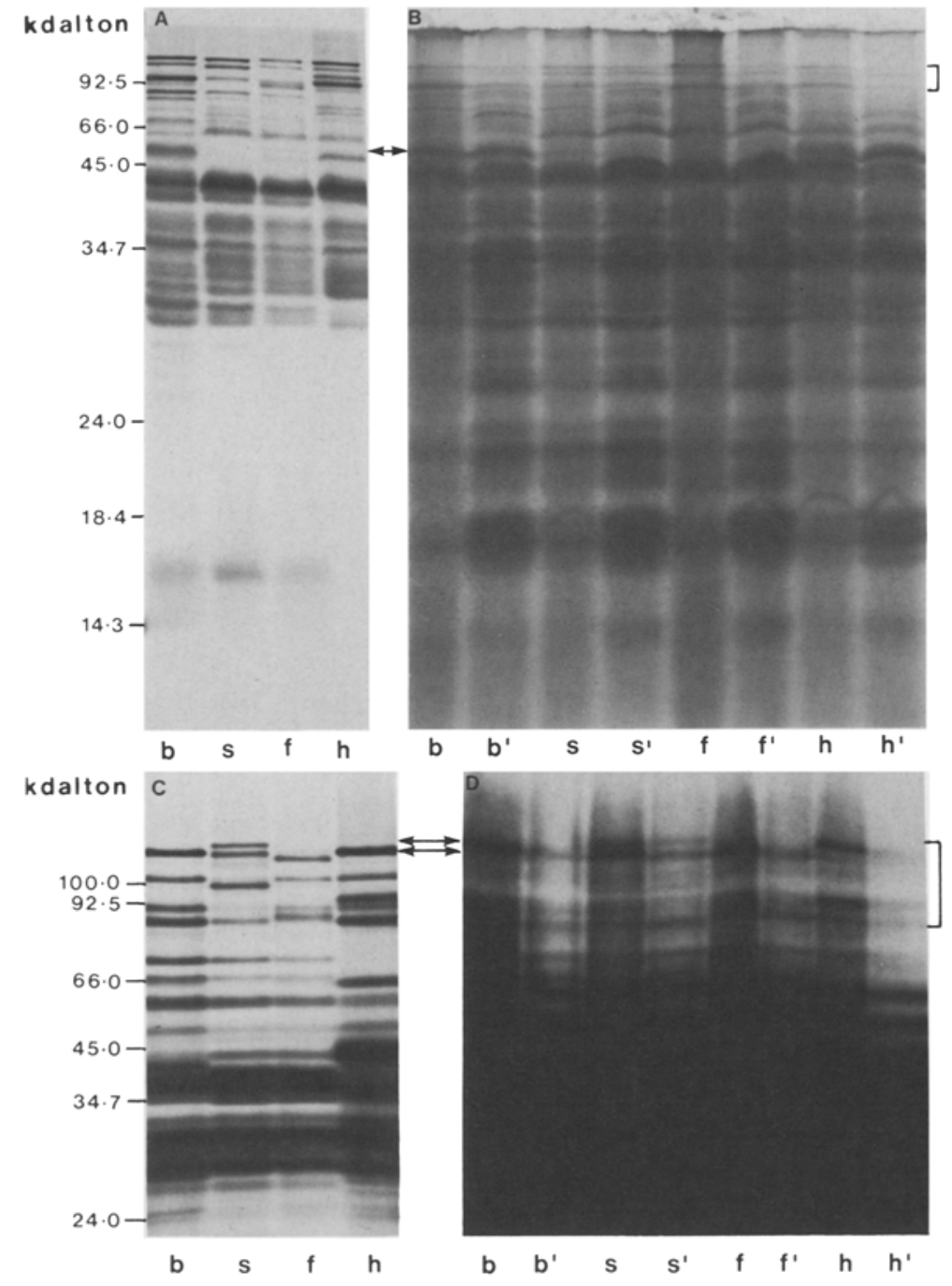

Fig. 4A-D. Synthesis of endosperm proteins from four wheat cultivars in vivo and in vitro. Analysis by SDS-PAGE of unalkylated proteins on $16 \%$ gels $(\mathbf{A}, \mathbf{B})$ and $8 \%$ gels $(\mathbf{C}, \mathbf{D})$. A, C Authentic prolamin polypeptides extracted from endosperm of four cultivars and stained with Coomassie Blue: $b$, Brigand; $s$, Sentry; $f$, Flanders; $h$, Highbury. B, D The in-vitro translation products of membrane-bound polysomes : $b$, Brigand; $s$, Sentry; $f$, Flanders; $h$, Highbury; and membrane-bound polysomal RNA: $b^{1}$, Brigand; $s^{1}$, Sentry; $f^{1}$, Flanders; $h^{1}$, Highbury. The arrows refer to polypeptides discussed in the text. The brackets indicate the position of the HMW prolamin polypeptides ing the preparation of poly $(\mathrm{A})^{+}$RNA by oligo(dT)-cellulose chromatography. The mRNAs may bind very tightly and not be eluted under the conditions used, or conversely, they may not be retained efficiently. It has been reported (Deeley et al. 1977; MacLeod et al. 1981) that large mRNAs bind less well than small ones to oligo (dT)-cellulose or to poly (U)-Sepharose, apparently due to steric hindrance rather than to the absence of a 3'-poly A tract.

The results shown in Fig. 4 demonstrate that the polysomal-RNA products give a polypeptide pattern very similar to that synthesised by polysomes from the same cultivar, and that this pattern compares well with that of the in-vivo proteins. The pattern of the authentic storage-protein polypeptides present in wheat endosperm is genetically determined (Elton and Ewart 1962; Wrigley and Shepherd 1974; Payne et al. 1981b). The patterns of HMW subunits present in cultivars Brigand, Sentry, Flanders and Highbury are shown on $16 \%$ and $8 \%$ polyacrylamide gels in Fig. $4 \mathrm{~A}$ and $\mathrm{C}$ respectively. To test if the HMW-translation products were also cultivar-specific, polysomes and polysomal RNA were isolated from the same cultivars, translated, and the products run on similar gels (Fig. 4B, D). It is apparent, particularly with the slower-migrating HMW polypeptides, that the translation products had similar mobilities to those of the authentic proteins e.g. see arrowed bands indicating subunits 1 and 3 of Sentry (classification of Payne et al. $1981 \mathrm{~b}$ ) in lanes $\mathrm{s}$ and $\mathrm{s}^{1}$ of Fig. 4C and $\mathrm{D}$. This correspondence is also seen in other regions of the gel: a polypeptide, possibly an $\omega$-gliadin, of about 55 kdalton, is clearly present in both the authentic proteins and the in-vitro translation products of Brigand (arrowed band in lanes $b$ and $b^{1}$ of Fig. $4 A$ and $B$ ) and absent in 


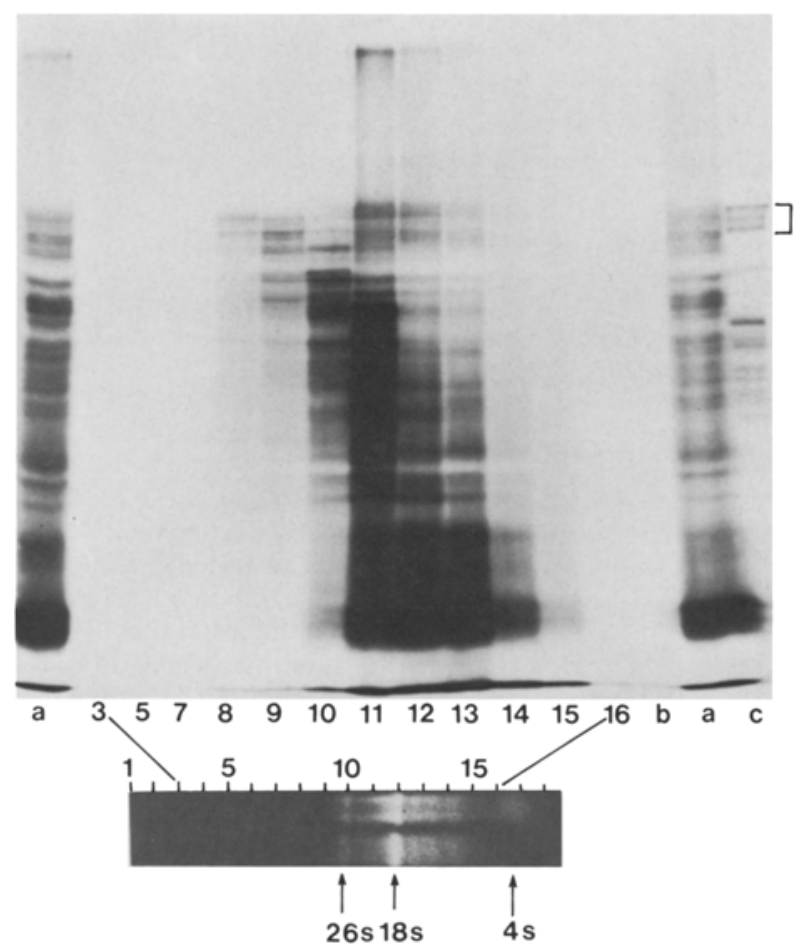

Fig. 5. Fractionation of wheat endosperm poly(A) ${ }^{+}$RNA (cv. Highbury) by methylmercury-agarose-gel electrophoresis. The RNA gel is shown below the fluorogram. Both tracks are of poly (A) ${ }^{+}$RNA; 4S RNA was added to one sample. The agarose gel was sliced and the RNA electro-eluted from the strips and translated in the reticulocyte lysate. The unalkylated products were run on $12 \%$ polyacrylamide gels and fluorographed. The numbers below the lanes of the fluorogram relate to the fractions from the RNA gel. Lane $a$, unfractionated poly(A) ${ }^{+}$RNA; $b$, no RNA control; $c$, radiolabelled pyridylethylated authentic prolamins. The bracket shows the position. of the HMW prolamin polypeptides

the cultivars Sentry and Flanders (Fig. 4A and B, lanes $\mathrm{s}$ and $\mathrm{s}^{1}$, $\mathrm{f}$ and $\mathrm{f}^{1}$.

Fractionation of $R N A$. Two methods were used to enrich for mRNA sequences coding for the HMW polypeptides. Firstly, poly(A) ${ }^{+}$RNA was fractionated on a methylmercury agarose gel, part of which was stained and photographed. The RNA fractions recovered from the rest of the gel were translated using a reticulocyte lysate. The results are shown in Fig. 5. The mRNAs contained in fractions 8 and 9 are enriched for those coding for HMW polypeptides, and have an estimated $\mathrm{M}_{\mathrm{r}}$ between 1.2 and $2.1 \cdot 10^{6}$.

The RNA was also fractionated using strongly denaturing sucrose gradients containing $95 \%$ dimethyl sulfoxide and 4\% formamide (see Material and methods). After centrifugation, the gradients were fractionated and those fractions where the mRNAs for the HMW polypeptides were expected (around 26S and above) were translated. The
$\mathrm{A}_{280 \mathrm{~nm}}$ profile of the gradient is shown in Fig. 6A, and the translation products of the RNA from the fractions are shown in the fluorogram below (tracks 10-13). By comparison with the translation products of unfractionated RNA (track b), enrichment is seen in these fractions for polypeptides of approx. 55 kdalton and above. However, contamination of the fractions with low-molecular-weight material is also apparent. This is probably due to aggregation of the RNA, resulting in low-molecular-weight RNA being dragged through the gradient. Fractions containing RNA encoding the HMW polypeptides and sedimenting at the peak of the 18S rRNA and below were pooled (see bar on Fig. 6A) and precipitated in the presence of added tRNA. This RNA was fractionated on a second sucrose gradient, the $A_{280 \mathrm{~nm}}$ profile of which is seen in Fig. 6B. The translation products of RNA from this gradient are shown in the fluorogram beneath its profile. This shows improved separation of the mRNAs, and fractions were obtained which were appreciably enriched in those coding for the HMW polypeptides (track 14). These mRNAs sedimented at the shoulder below the peak of the $26 \mathrm{~S}$ rRNA, indicating a molecular weight slightly above $1.3 \cdot 10^{6}$, the molecular weight for 26S rRNA (Dyer and Leaver 1981).

The success in using the reticulocyte lysate to translate these HMW polypeptides contrasts with our failure, and that of others, with the wheatgerm system. Greene (1981) and Okita and Greene (1982) also translated poly(A) ${ }^{+}$RNA from wheat endosperm using the wheat-germ extract, and obtained no evidence for polypeptides above 70 kdalton amongst the translation products. Donovan et al. (1982), using membrane-bound polysomal RNA, have also failed to translate these polypeptides. The difficulty in synthesising these large polypeptides in vitro using wheat germ may reflect the higher proportion of early termination products and the much lower translational activity of this system. Additionally, and with reference also to the reticulocyte lysate, it may be related to the poor ability of these mRNAs to compete against smaller-molecular-weight mRNAs for initiation of protein synthesis. This would explain the clear presence of the HMW polypeptides amongst the translation products of polysomes, since initiation has taken place and these are simply "run off" products. The results of the fractionation experiments also indicate that once the low-molecular-weight mRNAs are removed from the RNA preparation, HMW polypeptides are more readily synthesised.

We are now using cloned complementary-DNA 

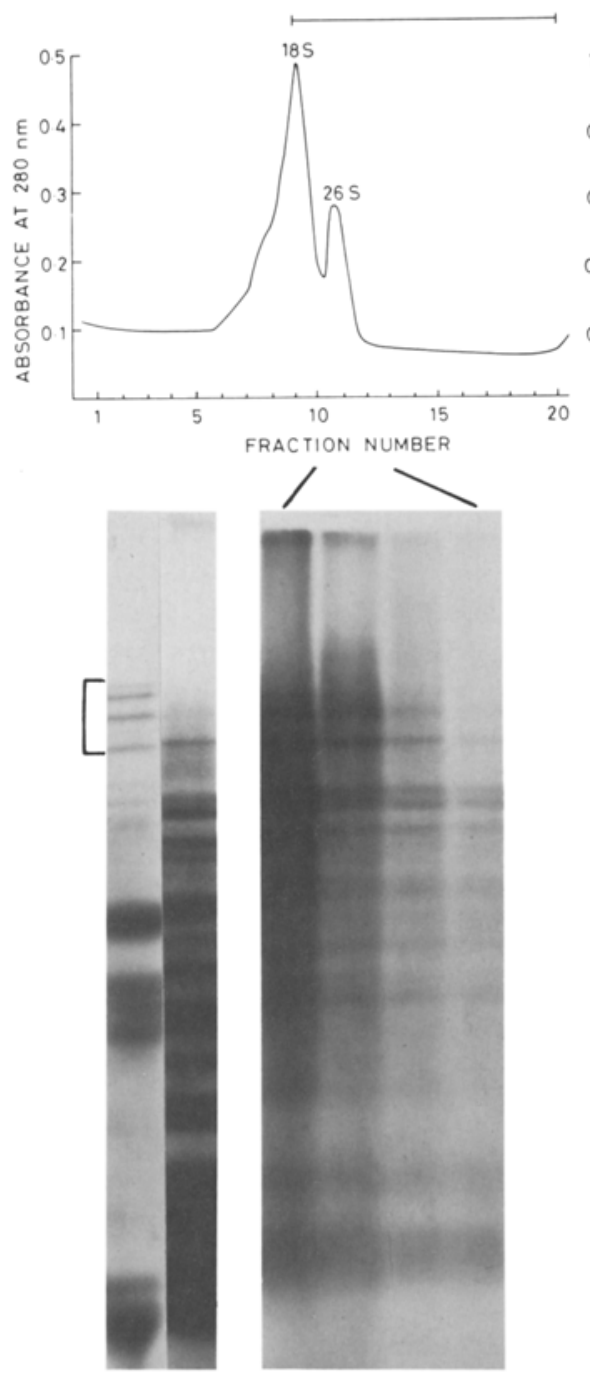

a b

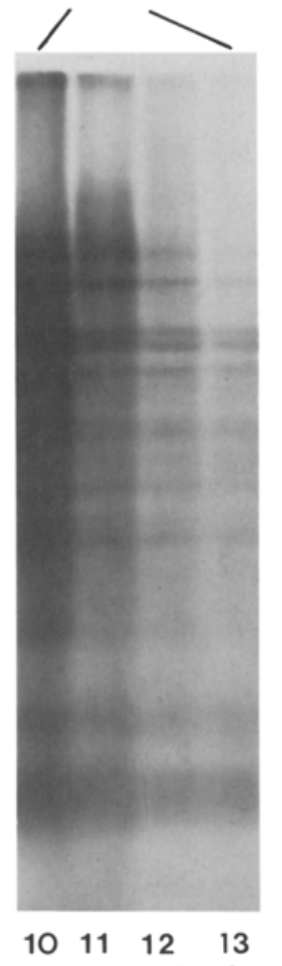

FRACTIONS
B

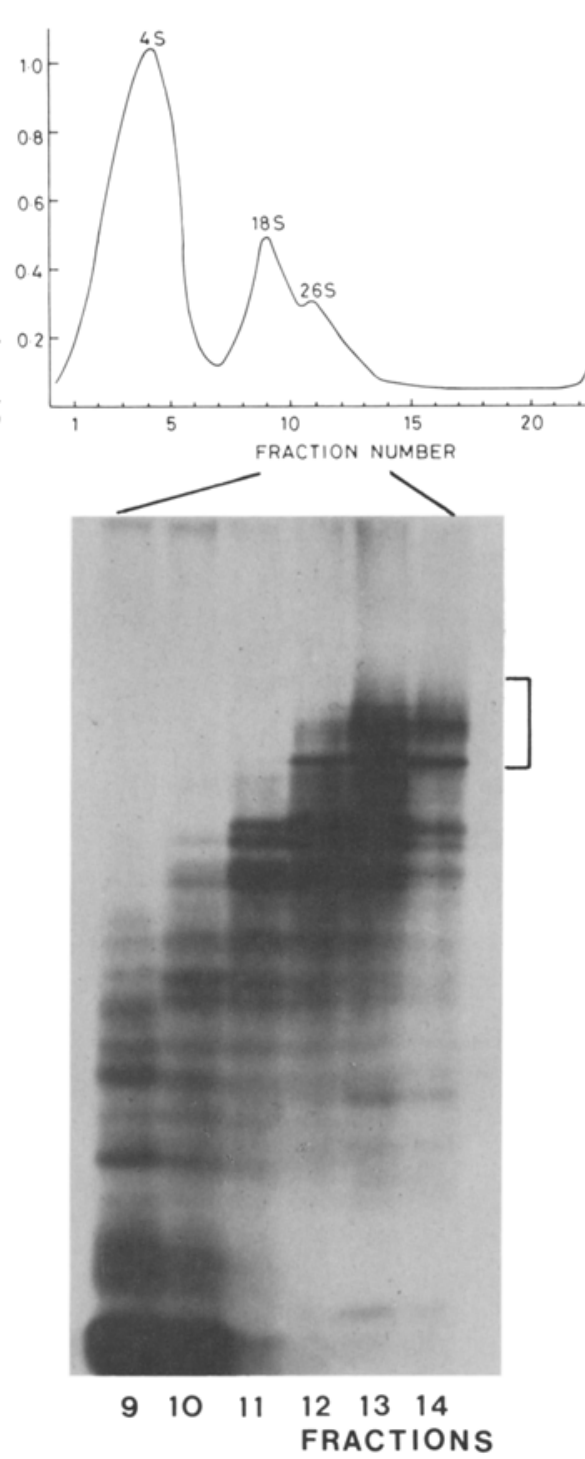

Fig. 6A, B. Fractionation of wheat endosperm poly(A) ${ }^{+}$RNA (cv. Sentry) by sucrose-densitygradient centrifugation. Poly $(\mathrm{A})^{+}$ RNA was heat treated and layered onto a strongly denaturing sucrose gradient as described in the text. After centrifugation, the gradients were fractionated and the $A_{280 \mathrm{~nm}}$ profile was recorded (A). Fractions containing mRNAs for the HMW polypeptides were identified by cell-free translation using the reticulocyte lysate. Fractions, from the peak of the 18S RNA and below, were pooled (see bar on A) and re-centrifuged on a second sucrose gradient, the $A_{280}$ profile of which is seen in $\mathbf{B}$. The RNA from each fraction was translated and analysed by SDSPAGE and fluorography. The fluorograms are shown below the gradient profiles: the lane number corresponds with the sucrosegradient fraction number. Lane $a$, radiolabelled authentic prolamins; $b$, unfractionated poly $(\mathrm{A})^{+}$ RNA. The brackets indicate the position of the HMW prolamin polypeptides sequences to study in more detail the mRNAs encoding the HMW polypeptides.

\section{Conclusion}

High-molecular-weight polypeptide components of wheat storage proteins have been identified amongst the translation products of polysomes and RNA isolated from developing wheat endosperms. Four criteria for identification have been used:

i) their solubility in acidic aqueous alcohol solutions;

ii) their incorporation of large amounts of $\left[{ }^{3} \mathrm{H}\right] l$ leucine and particularly $\left[{ }^{3} \mathrm{H}\right] \mathrm{glycine}$ relative to $\left[{ }^{3} \mathrm{H}\right]$ lysine, in agreement with their known amino aid composition;

iii) their mobility on SDS-PAGE;

iv) the relative mobilities of the HMW polypeptides synthesised in vitro which are cultivar specific and vary in a similar way to the authentic, in-vivo synthesised components.

The mRNAs for the HMW components have an apparent $M_{r}$ of about $1.6 \cdot 10^{6}$. These mRNAs are not readily translated in a wheat-germ system but can be more easily translated by a rabbit reticulocyte lysate, especially when purified.

The authors would like to thank M. Kreis, P.P. Shewry and B.G. Forde, for their advice and help with this work. We would 
also like to thank J.D. Marriage for supplying the wheat germ and M. Wilson and J. Carr for providing the reticulocyte lysate.

\section{References}

Bailey, J.M., Davidson, N. (1976) Methylmercury as a reversible denaturing agent for agarose gel electrophoresis. Anal. Biochem. 70, 75-85

Bantle, J.A., Maxwell, I.H., Hahn, W.E. (1976) Specificity of oligo (dT)-cellulose chromatography in the isolation of polyadenylated RNA. Anal. Biochem. 72, 413-427

Beachy, R.N., Barton, K.A., Thompson, J.F., Madison, J.T. (1980) In vitro synthesis of the $\alpha$ and $\alpha^{1}$ subunits of the $7 \mathrm{~S}$ storage proteins (conglycinin) of soybean seeds. Plant Physiol. 65, 990-994

Bietz, J.A., Huebner, F.R., Sanderson, J.E., Wall, J.S. (1977) Wheat gliadin homology revealed through $\mathrm{N}$-terminal amino acid sequence analysis. Cereal Chem. 54, 1070-1083

Brandt, A., and Ingversen, J. (1976) In vitro synthesis of barley endosperm proteins on wild type and mutant templates. Carlsberg Res. Commun. 41, 311-320

Burr, B., Burr, F. (1976) Zein synthesis in maize endosperm by polyribosomes attached to protein bodies. Proc. Natl. Acad. Sci. USA 73, 515-518

Byers, M., Miflin, B.J., Smith, S.J. (1983) A quantitative comparison of the extraction of protein fractions from wheat grain by different solvents, and of the polypeptide and amino acid composition of the alcohol-soluble proteins. J. Sci. Food Agric. (in press)

Chamberlain, J.P. (1979) Fluorographic detection of radioactivity in polyacrylamide gels with the water-soluble fluor, sodium salicylate. Anal. Biochem. 98, 132-135

Dayhoff, M.O. (1972) Atlas of protein sequence and structure. National Biochemical Research Foundation, Georgetown University Medical Centre, Washington

Deeley, R.G., Gordon, J.I., Burns, A.T.H., Mullinix, K.P., Binastein, M., Goldberger, R.F. (1977) Primary action of the vitellogenin gene in the rooster. J. Biol. Chem. 252, $8310-8319$

Donovan, G.R., Lee, J.W., Longhurst, T.J. (1982) Cell-free synthesis of wheat prolamins. Aust. J. Plant Physiol. 9, $59-68$

Dottavio-Martin, D., Ravel, J.M. (1978) Radiolabelling of proteins by reductive alkylation with $\left[{ }^{14} \mathrm{C}\right]$ formaldehyde and sodium cyanoborohydride. Anal. Biochem. 87, 562-565

Dyer, T.A., Leaver, C.J. (1981) RNA: structure and metabolism. In: The biochemistry of plants, Vol. 6. Proteins and nucleic acids, pp. 113-162. Stumpf, P.K., and Conn, E.E., eds., Academic Press, London

Elton, G.A.H., Ewart, J.A.D. (1962) Starch gel electrophoresis of cereal proteins. J. Sci. Food Agric. 13, 62-72

Ewart, J.A.D. (1972) Re-examination of the linear glutenin hypothesis. J. Sci. Food Agric. 28, 191-199

Field, J.M., Shewry, P.R., Miflin, B.J., March, J.F. (1982) The purification and characterisation of homologous high molecular weight storage proteins from grain of wheat, rye and barley. Theor. Appl. Genet. 62, 329-336

Field, J.M., Shewry, P.R., Burgess, S.R., Forde, J., Parmar, S., Miflin, B.J. (1983) The presence of large molecular weight protein aggregates in the protein bodies of developing wheat and other cereal grains. J. Cereal Sci, 33-41

Forde, B., Kreis, M., Bahramian, M.B., Matthews, J., Miflin, B.J., Thompson, R.D., Bartels, D., Flavell, R.B. (1981) Molecular cloning and analysis of cDNA sequences derived from Poly $\mathrm{A}^{+}$RNA from barley endosperms : identification of B hordein related clones. Nucl. Acids Res. 9, 6689-6707
Fox, J.E., Pratt, H.M., Shewry, P.R., Miflin, B.J. (1977) The in vitro synthesis of hordeins with polysomes from normal and high lysine varieties of barley. In: Nucleic acid and protein synthesis in plants, pp. 501-509, Centre National de la Recherche Scientifique, Paris

Greene, F.C. (1981) In vitro synthesis of wheat (Triticum aestivum L.) storage proteins. Plant Physiol. 68, 778-783

Kahn, K., Bushuk, W. (1979) Studies of glutenin-XIII-Gel filtration, isolelctric focusing, and amino acid composition studies. Cereal Chem. 56, 505-512

Kasarda, D.D., Bernardin, J.E., Nimmo, C.C. (1976) Wheat proteins. In: Advances in cereal science and technology, vol. 1, pp. 158-236, Y. Pomeranz, ed. Am. Assoc. Cereal Chem., St. Paul, Minn., USA

Laemmli, U.K. (1970) Cleavage of structural proteins during the assembly of the head of bacteriophage T4. Nature (London) 227, 681-685

Larkins, B.A., Dalby, A. (1975) In vitro synthesis of zein-like proteins by maize polyribosomes. Biochem. Biophys. Res. Commun. 66, 1048-1054

MacLeod, A.R., Karn, J., Brenner, S. (1981) Molecular analysis of the unc-54 myosin heavy-chain gene of Caenorhabditis elegans. Nature (London) 291, 386-390

Matthews, J.A., Miflin, B.J. (1980) In vitro synthesis of barley storage proteins. Planta 149, 262-268

Miflin, B.J., Shewry, P.R. (1979) The biology and biochemistry of cereal seed prolamins. In: Seed improvement in cereals and grain legumes, vol. 1., pp. 137-158. Int. Atomic Energy Authority, Vienna

Miflin, B.J., Byers, M., Field, J.M., Faulks, A.J. (1980) The isolation and characterisation of proteins extracted from whole milled seed, gluten and developing protein bodies of wheat. Ann. Technol. Agric. 29, 133-147.

Miflin, B.J., Burgess, S.R., Shewry, P.R. (1981) The development of protein bodies in the storage tissue of seeds: subcellular separations of homogenates of barley, maize and wheat endosperms and of pea cotyledons. J. Exp. Bot. 32, 199-219

Miflin, B.J., Field, J.M., Shewry, P.R. (1983) Cereal storage proteins and their effect on technological properties. In: Seed proteins, pp. 255-319, Daussant, J., Mosse, J., Vaughan, J., eds. Academic Press, London

Okita, T.W., Greene, F.C. (1982) Wheat storage proteins. Isolation and characterisation of the gliadin messenger RNAs. Plant Physiol. 69, 834-839

Osborne, T.B. (1924) The vegetable proteins. Longmans Green \& Co., London

Payne, P.I., Corfield, K.G., Blackman, J.A. (1979) Identification of a high-molecular-weight subunit of glutenin whose presence correlates with bread-making quality in wheats of related pedigree. Theor. Appl. Genet. 55, 153-159

Payne, P.I., Law, C.N., Mudd, E.E. (1980) Control by homoeologous group 1 chromosomes of the high-molecular-weight subunits of glutenin, a major protein of wheat endosperm. Theor. Appl. Genet. 58, 113-120

Payne, P.I., Corfield, K.G., Holt, L.M., Blackman, J.A. (1981 a) Correlations between the inheritance of certain high-molecular-weight subunits of glutenin and bread-making quality in progenies of six crosses of bread wheat. J. Sci. Food Agric. 32, 51-60

Payne, P.I., Holt, L.M., Law, C.N. (1981 b) Structural and genetical studies on the high-molecular-weight subunits of wheat glutenin. Part 1: Allelic variation in subunits amongst varieties of wheat (Triticum aestivum). Theor. Appl. Genet. 60, 229-236

Payne, P.I., Rhodes, A.P. (1982) Cereal storage proteins: structure and role in agriculture and food technology. In: Encycl. 
Plant Physiol., N.S., vol. 14A: Nucleic acids and proteins in plants 1 : Structure, biochemistry and physiology of proteins. pp. 346-369. Boulter, B., Parthier, B., eds. Springer, Berlin Heidelberg New York

Payne, P.I., Holt, L.M., Worland, A.J., Law, C.N. (1983) Structural and genetical studies on the high-molecular-weight subunits of wheat glutenin. Part III: Telocentric mapping of the subunit genes on the long arms of the homoeologous group 1 chromosomes. Theor. Appl. Genet. 63, 129-138

Pelham, H.R.B., Jackson, R.J. (1976) An effcient mRNA-dependent translation system from reticulocyte lysates. Eur. J. Biochem. 67, 247-256

Pence, J.W., Elder, A.H. (1953) The albumin and globulin proteins of wheat. Cereal Chem. 30, 275-287

Roberts, B.E., Paterson, B.M. (1973) Efficient translation of TMV RNA and rabbit globin 9S RNA in a cell-free system from commercial wheat germ. Proc. Nat. Acad. Sci. USA. 70, 2330-2339

Shewry, P.R., Autran, J.C., Nimmo, C.C., Lew, E.J.-L., Kasarda, D.D. (1980) N-terminal amino acid sequence homology of storage protein components from barley and diploid wheat. Nature (London) 286, 520-522

Wienand, U., Feix, G. (1978) Electrophoretic fractionation and translation in vitro of Poly(rA)-containing RNA from maize endosperm. Eur. J. Biochem. 92, 605-611

Wrigley, C.W., Shepherd, K.W. (1974) Identification of Australian wheat cultivars by laboratory procedures: examination of pure samples of grain. Aust. J. Exp. Agric. 14, 796-810

Received 18 November 1982; accepted 18 January 1983 